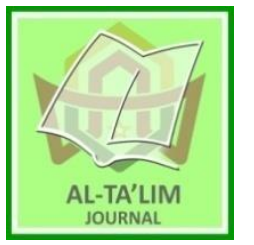

AL-TA'LIM JOURNAL, 28 (2), 2021, (145-154)

(Print ISSN 1410-7546 ISSN Online 2355-7893)

Available online at http://journal.tarbiyahiainib.ac.id/index.php/attalim

\title{
The Effect of Online Lecture on College Students' Learning Achievement During the Covid-19 Pandemic
}

Received: 13 ${ }^{\text {th }}$ June 2021; Revised: 28 ${ }^{\text {th }}$ July 2021; Accepted: $31^{\text {th }}$ Juli 2021

Permalink/DOI: http://dx.doi.org/10.15548/10.15548/it.v28i2.713

\section{Khalilah Ramadhani}

Universitas Islam Negeri Maulana Malik Ibrahim Malang, Indonesia

E-Mail: ramadhani.khalilah22@gmail.com

\begin{abstract}
College student learning achievement shows a reflection of mastery of knowledge both in quality and quantity which is influenced by several factors. This study was conducted to determine the influence of lecturers' teaching factors, interactive media, and learning motivation on college student learning achievement during the Covid-19 pandemic. The approach used in the reseach is quantitative with 50 college students from three different universities as reseach subjects. Data were collected through a questionnaire instrument google form by method simple random sampling or randomly selected. Then analyzed using multiple logistic regression analysis technique with the help of SPSS for windows. This study shows the results that the teaching of lecturer has no effect on increasing college student learning achievement, but interactive media and learning motivation have a positive effect on college student learning achievement. This study recommends further research to examine the effect of lecturer competence on online lectures during the Covid-19 pandemic.
\end{abstract}

Keywords: Lecturer teaching; interactive media; learning motivation; college student learning achievement.

How to Cite: Ramadhani, K. (2021). The Effect of Online Lecture on College Students' Learning Achievement During the Covid-19 Pandemic. Al-Ta lim Journal, 28(2), 144-153. doi:https://doi.org/10.15548/jt.v28i2.713

\section{INTRODUCTION}

The quality of education is an indicator of the success of education in the world, including Indonesia. One of the institutions that play an active role in preparing competent graduates in accordance with the goals of the national education system is higher education. The quality of higher education can be seen from the good or bad input, process, and output produced. This input aspect consists of human resources or lecturers, education staff and college students. Input is also in the form of infrastructure that supports learning as well as input of expectations to be achieved in the form of goals, vision, mission, and goals of the university (Wahyudi \& Ratna Sari, 2019). The success of educational practice in schools is based on the quality of its human resources. Educators can advance a nation by providing good education to students (Miguel \& Santos, 2021). The development of science and technology produced is also an indicator of the progress of a country (A. W. Ritonga, Zulfida, et al., 2021).

Rosyada suggests the categories that educators must have, namely capability and loyalty, namely the abilities that must be possessed in teaching both from planning, teaching to reviewing results, and having high 
standards of loyalty to responsibilities before and after in class (Arafah, 2017). Wahyudi \& Ratna Sari (2019) stated that this series of processes can change inputs into outputs in the form of synergy between lecturers and college students who utilize various methods and strategies in managing learning activities to vary. However, since Indonesia was exposed to Covid-19 and the government set rules for studying at home in mid-2020, it has changed the face of Indonesian education to date. The existence of Covid-19 is like lightning during the day, people are shocked by the new situation they are facing, including the condition of education (Apriyanto \& Herlina, 2020).

This requires a lecturer to maximally seek to solve educational problems by looking for learning methods and strategies. Until lecturers use available online media to carry out the teaching and learning process. Many obstacles were encountered during the implementation of distance learning, ranging from the unpreparedness of lecturers and college students to use online media to technical, network, and financial constraints that made the effectiveness of learning difficult to measure. This obstacle becomes a new challenge for lecturers in order to maintain and increase college student learning motivation in achieving achievement development that is in line with expectations.

The development of the quality of education in Indonesia still shows a low number compared to other countries. The government's seriousness in overcoming this problem is manifested by perfecting the education system at every level of education and every year (A. W. Ritonga, Ritonga, et al., 2021). During the Covid-19 pandemic, educators greatly affect the learning process so that it is productive whether it is done online or not online or through chat applications. This becomes important in creating comfort and building student motivation during the learning process.

Learning motivation is one of the internal factors that influence college student learning achievement. Behavior change will not occur if there is no motivating factor for college students to be active in learning. If college students have low motivation for a lesson, their ability in that field will be hampered. This is even more so when the Covid-19 pandemic makes it difficult for lecturers and college students to carry out distance learning (M. Ritonga et al., 2021). Learning motivation can decrease due to unpleasant learning done at home. College student pay less attention to the material explained by the lecturer so that there is a lack of participation during discussions. This reflects the low learning motivation of students which will affect their learning achievement achieved.

Learning achievement is the output of a series of learning activities in university. Readiness input high, effective educational process, can produce better higher education ouput (Winata, 2021). College student learning achievement is the real ability of measuring the knowledge, skills and attitudes of college students active interactions towards learning objects (A. W. Ritonga et al., 2020). Internal and external factors can affect the achievement of learning achievement. External factors come from the surrounding environment such as the conditions and circumstances of educational institutions. Internal factors appear as encouragement from within such as psychological aspects and physical conditions.

College student learning achievement can be influenced by external factors including interactive media and lecturer teaching. The existence of this interactive media is very supportive of teaching and learning activities. The availability and completeness of interactive media used greatly affects the learning process followed by college students so that it affects the achievements achieved. As research conducted by Amelia (2019) which states that the completeness of interactive media is very influential in learning success and the lack of complete interactive media can hinder learning progress.

Another influential external factor is the teaching of lecturers Sur et al., (2020) in his research stated that based on Law no. 14 
of 2005 article 69 paragraph 2 concerning the four competencies of educators, only pedagogic competence has a significant influence on increasing college student learning achievement. In line with the research of Murti \& Prasetio (2018) that lecturers who are professional and responsible for their duties are very much needed by universities in developing science and technology so that they can improve academic achievement achieved by college students.

Learning motivation is an internal factor that can affect college student learning achievement (Senjahari et al., 2021). The concept of learning motivation can put college students able to identify, understand, apply and control emotions. Skills interpersonal and important communication is built on the basis of learning motivation (Kumar et al., 2015). Akmal et al., (2013) states that if someone has high learning motivation, it can be beneficial for individuals in the process of education or career development.

Based on the description above, there are several things that can affect college student learning achievement. This new phase experienced by elements of education after entering the Covid-19 pandemic brought various impacts on education policies at each university. Therefore, this study aims to measure the influence of lecturer teaching, interactive media, and learning motivation on college student learning achievement during the Covid-19 pandemic.

\section{Research Hypotheses}

Based on previous research, related to external and internal factors that affect college student achievement, the researcher proposes the following hypothesis:

Based on Law No. 14 of 2005 article 1 concerning teachers and lecturers, that lecturers are professional educators who have the main task of developing and disseminating knowledge, artistic creativity and technology development through education. This illustrates the task of lecturers professionally is to distribute knowledge to college students through the learning process. Based on Law no. 12 of 2012 article 12 as an academic community, lecturers are tasked with transforming the knowledge and technology they master to college students by realizing learning plans, implementation, and paying attention to a good learning atmosphere so that college students are able to increase their potential. As research conducted by Mustaqim (2020) suggests that there is a significant relationship between college student learning achievement and lecturer qualifications. Supported by Alam (2018) research which found that there is a significant relationship between college student learning achievement and the influence of lecturers teaching competencies. Based on the description above, the hypotheses that can be formulated are:

$\mathrm{H}_{1}$ : Lecturer teaching has a positive relationship to college student learning achievement.

Nkomo et al., (2021) stated that educational facilities consist of facilities as equipment that is used directly during the learning process, and infrastructure which is a component of supporting the learning process. Ramdani et al., (2020) suggest that interactive media is a tool that is directly used during learning. Research conducted by Mushtaq \& Khan (2012) shows the finding that interactive media has a positive effect on college students willingness to learn. Ramli et al., (2018) in his research stated that the learning environment accompanied by the availability of good infrastructure had a positive effect on the academic achievement of college students. It is also stated by Uline et al., (2008) namely the quality of learning media has an effect on increasing college student learning achievement. Based on the description above, the hypotheses that can be formulated are:

$\mathrm{H}_{2}$ : Interactive media has a positive relationship to college student learning achievement.

Learning motivation is an encouragement so that someone is in learning activities, solving problems, create the 
conditions he wants in achieving the best results. Motivation to learn can come from the personal self and the surrounding environment which will form the psychological conditions for concentration. High learning motivation can place college students in activeness when participating in the learning process so that they can easily obtain the desired learning outcomes. Handhika (2012) states that learning motivation is one of the important element that greatly affect the success of student learning. Syachtiyani \& Trisnawati (2021) also stated in their findings that there is a positive influence between learning motivation and improving student achievement. The same thing was also stated by Winata (2021) in his research that learning motivation showed a positive significance to the performance of the quality of achievement achieved by students. Based on the description above, the hypotheses that can be formulated are:

$\mathrm{H}_{3}$ : Learning motivation has a positive relationship to college student learning achievement.

\section{METHOD}

Researchers measured this relationship to 50 college students online in the Covid-19 pandemic era. As many as 50 college students became key informants spread across three universities, namely UIN Imam Bonjol Padang, UIN Suska RIAU, and Universitas RIAU to obtain in-depth information about the influence of lecturer teaching, interactive media, and learning motivation on college student learning achievement during the Covid-19 pandemic.

The approach used is quantitative to measure the effect of learning objects in increasing college student achievement in online learning challenges. The data collection of lecturers' teaching, interactive media, and college student learning motivation was taken by sending a google form questionnaire to the subject's or college student's WhatsApp which was measured using a scale Likert four-point.
Questionnaires were distributed to get college students individual views on online learning.

The research sample is a small number used in collecting data that can represent the population. This sampling uses a simple random sampling method, namely sampling in the population is carried out randomly regardless of the semester in the population because all college students study online. This sample consisted of 15 respondents from UIN Imam Bonjol Padang, 17 respondents from UIN Suska RIAU and 18 respondents from RIAU University. From the data collected, it is processed using multiple logistic regression analysis techniques. The results of data processing and analysis were obtained after testing using SPSS version 25.

\section{RESULT AND DISCUSSION}

This study has a research subject of 50 respondents who are randomly distributed in three universities, namely UIN Imam Bonjol Padang, UIN Suska RIAU and Universitas RIAU. Each university is divided into 15 respondents from UIN Imam Bonjol Padang, 17 respondents from UIN Suska RIAU and 18 respondents from RIAU University.

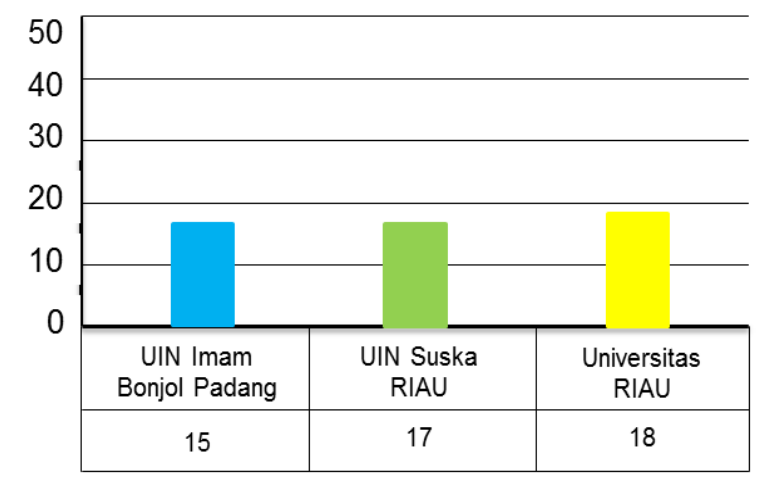

Figure 1. Respondent University

Seeing the condition of education entering a new stage during the Covid-19 pandemic, of course there are various challenges and conditions that have an impact on learning. This has an impact on the college process that college students undergo. Therefore, it is necessary to do research on the factors that can affect student achievement. The research data was taken through an instrument distributed on college students WhatsApp in the form of a 
questionnaire in the google form which consisting of 3 aspects of questions. Questions about teaching lecturers that started from the first meeting were lecture contracts, the process of implementing online lectures to the form of evaluation given by lecturers to college students. Questions about interactive media about the effectiveness of the use of learning media used by lecturers and college students in the learning process. While the question of learning motivation consists of internal and external aspects that can affect college student learning motivation. The question indicators are adjusted to the conditions faced by educational institutions and educational personnel during the Covid19 pandemic.

Table 1. Percentage of Data Processing Results

\begin{tabular}{lcccc}
\hline \multicolumn{1}{c}{ Factor } & $\begin{array}{c}\text { Very } \\
\text { Statisfied }\end{array}$ & Satisfied & Fairly & Poor \\
\hline $\begin{array}{l}\text { Lecturer } \\
\text { teaching }\end{array}$ & $11.8 \%$ & $56.8 \%$ & $29.4 \%$ & $2 \%$ \\
$\begin{array}{l}\text { Interactive } \\
\text { media }\end{array}$ & $41.2 \%$ & $41.2 \%$ & $17.6 \%$ & $0 \%$ \\
$\begin{array}{l}\text { Learning } \\
\text { motivation }\end{array}$ & $26.5 \%$ & $58.8 \%$ & $12.7 \%$ & $2 \%$ \\
\hline
\end{tabular}

Table 1 shows the results of measurements of factors that affect college student learning achievement. The influence of lecturer teaching, interactive media, learning motivation was measured using a 4point Likert Scale with categories of very satisfied, satisfied, fairly, and poor.

Table 2. Model Goodness Test

\begin{tabular}{|c|c|c|c|}
\hline \multicolumn{4}{|c|}{ Goodness-of-Fit } \\
\hline & Chi-Square & Df & Sig. \\
\hline Pearson & 336,164 & 89 & 000 \\
\hline Deviance & 52,355 & 89 & ,999 \\
\hline
\end{tabular}

The table above shows that through the Deviance method the value is known ChiSquare of 52,355. The test can be done with criteria reject $\mathrm{H}_{0}$ if the significance value of less than $0.1(\alpha=0,1)$. In the table show that the Deviance test value has a significance value of 0.999 . Taken a decision that $\mathrm{HO}$ is accepted because the significance value greater than 0.1. Based on the logit obtained, this model is feasible to use.

The results of the estimation of the ordinal logistic regression model on the independent variables, namely lecturer teaching, interactive media, and learning motivation on the dependent variable, namely college student learning achievement can be seen in the following table:

Table 3. Regression Equation and Wald's Test

Parameter Estimates

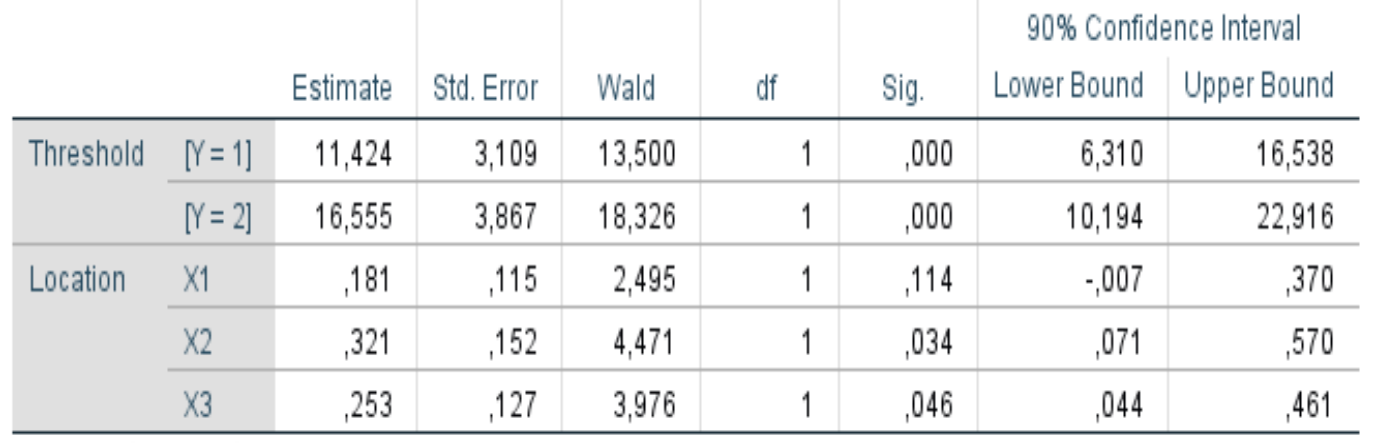

Link function: Logit.

The logistic regression equation resulting from the above output is: $\operatorname{Logit}\left(Y_{1}\right)=11.424+0.181 x_{1}+0.321 x_{2}+$ $0.253 x_{3}$

$$
\operatorname{Logit}\left(Y_{2}\right)=16.555+0.181 x_{1}+0.321 x_{2}+
$$

These results indicate that the value $\theta$ is a constant variable value, namely the value shown in the line of Threshold the column 
Estimate with the numbers 11.424 and 16.555. While the value in the line Location the column Estimate is a predictor variable of $0.181,0.321,0.253$.

From the table above for Wald's test, it can be seen that the lecturer teaching variable (X1) has a significance value of 0.114 . This value is greater than alpha $(0.114>0.1)$. This shows that the teaching of lecturers does not affect college student learning achievement. The interactive media variable (X2) has a significance of 0.034 . This value is smaller than alpha $(0.034<0.1)$. This shows that interactive media affect college student learning achievement. The learning motivation variable (X3) has a significance of 0.046. This value is smaller than alpha $(0.046<0.1)$. This shows that learning motivation affects college student learning achievement.

In general, the constants and regression coefficients of the learning media variables (X2) and learning motivation (X3) are positive, meaning that the relationship between the independent variable and the dependent variable is one-way positive. This means that the more effective the learning media, the more likely it is to increase college student learning achievement.

The ordinal logistic regression model after being tested got good model results, the significance is clear so that the results can be interpreted with the odds ratio test. The results of the teaching aspect ratio of lecturers $(\mathrm{X} 1): \Psi=\operatorname{Exp}(0.181)=1.199$. This means that the opportunity to increase college student learning achievement from the influence of lecturer teaching is 1.199 times compared to college students who do not experience an increase in learning achievement. Interactive media aspect ratio odds (X2): $\Psi=\operatorname{Exp}(0,321)=1.379$. This means that the opportunity to increase college student learning achievement from the influence of interactive media is 1.379 times compared to college students who do not experience an increase in learning achievement. Odds ratio aspect of learning motivation (X3): $\Psi=\operatorname{Exp}(0,253)=1,288$. This means that the opportunity to increase college student learning achievement from the influence of learning motivation is 1.288 times compared to college students who do not experience an increase in learning achievement.

Table 4. Determinant Coefficient Value

Pseudo R-Square

\begin{tabular}{lc} 
Cox and Snell &, 490 \\
\hline Nagelkerke &, 587 \\
\hline McFadden &, 374 \\
\hline Link function: Logit.
\end{tabular}

The table above shows Mc. Fadden has a coefficient of determination of 0.374 while Cox and Snell have a coefficient of determination of 0.490 and Nagelkerke has a coefficient of determination of 0.587 or $58.7 \%$. Nagelkerke shows a coefficient value of $58.7 \%$ which means that aspects of lecturer teaching, interactive media, and learning motivation as independent variables affect the level of college student learning achievement in general by $58.7 \%$ while $41.3 \%$ consists of other factors that can affect college student learning achievement.

After testing the hypothesis, the results illustrate that the relationship between lecturers' teaching and college student learning achievement shows a positive regression value of 0.181 and a significance of 0.114 which is greater than $(0.1)$. This means that there is no influence of lecturer teaching on college student learning achievement. Analysis of the research data rejected the first hypothesis because lecturer teaching has no significant effect on college student learning achievement. This study supports the findings of Al-mutairi (2011), Abbasi \& Mir (2012), Bonney et al., (2015) that there is no positive effect of lecturer teaching quality on college student achievement. In contrast to research conducted by Murti \& Prasetio (2018), Hakim (2015), Wahyudi \& Ratna Sari (2019), and Buska (2020) that the ability of lecturers to teach has a positive effect on college student learning achievement. From the results it is understood that university have an important responsibility in paying attention to their personal knowledge, competence and abilities 
so that lecturers can improve their professionalism and be able to influence the improvement of college student learning achievement.

Learning both formally and nonformally tends to take the model as an object of observation. Through observation, college students can remember and understand what they see. The behavior, learning methods, mentoring and evaluation provided by the lecturer are the center of college student attention. So that if the lecturer shows competence and attitudes that are in accordance with the needs of college students, it can have an impact on college student learning achievement. This illustrates that the analysis can be carried out further with a model of the description of the lecturer's teaching quality.

Indicators that can describe the quality of teaching lecturers are the ability of the lecturer to explain the lecture material, the ability of the lecturer to provide reinforcement, the ability of the lecturer to provide value to college student learning outcomes, and the ability of the lecturer to use information technology as a learning medium. This is supported by research conducted by Rahmi (2021) that digital teaching materials need to be prepared by lecturers by paying attention to design principles. So that it is able to familiarize creative college students in $21 \mathrm{st}$ century learning that utilizes e-learning facilities. The results indicate that qualified lecturers can create an effective learning atmosphere, and an effective learning atmosphere is able to build college student learning motivation and in the end be able to improve college student learning achievement.

The results of the hypothesis test above illustrate that the effect of learning motivation on college student achievement shows a positive regression value of 0.321 and a significance of 0.034 which is smaller than (0.1). This result means that it shows the positive influence of interactive media on college student learning achievement. The results presented by this research support the second hypothesis that there is an influence of interactive media on college student learning achievement. This study supports the findings of Akomolafe et al., (2016), Hew et al., (2020), Munastiwi (2020), Technol et al., (2021) that there is a positive influence of interactive media on academic achievement. Nirfayanti \& Nurbaeti (2019) in their research stated that college student learning outcomes showed differences in the high category after the use of learning media in mathematics studies with an average score of 78.31 .

The learning process occurs because of the interaction between lecturers and college students through applications and learning media that support distance learning. Utilization of this facility will affect the improvement of college student achievement on a regular basis. Advances in science and technology in interactive media can build college student motivation and the development of knowledge is easier for college students by visualizing abstract material into more interesting animations according to conditions in the field. Ahmed \& Alzubi (2021) in their research explain that there is a mismatch between knowledge and practice in the application of mobile applications. Thus, it is necessary to hold appropriate professional training activities and according to the field.

The results of the hypothesis test above illustrate that the relationship between learning motivation and college student learning achievement shows a positive regression value of 0.253 and a significance of 0.046 which is smaller than $(0.1)$. These results mean that there is a significant positive relationship between learning motivation on college student learning achievement. The results presented by this study support the third hypothesis that learning motivation has a positive influence on college student learning achievement.

Leitão et al., (2021) in their research suggests that learning motivation and guidance by educators have a good relationship with college student learning achievement. Handhika (2012), Khoiroh et.al., (2017) in their research also suggests that college students who have high learning 
motivation have more influence on improving learning outcomes compared to college students with low motivation. This research was supported by Syachtiyani \& Trisnawati (2021) that learning motivation has an effect on college student learning achievement. Tokan \& Imakulata (2019), stated the results of their research that learning motivation is one of the factors that can affect the learning outcomes achieved by college student.

This illustrates that the analysis can be carried out further with a good model. Indicators of college student learning motivation are trying to be tenacious in dealing with problems, needs, completing assignments, expectations of success, enthusiasm for learning, and initiative. The level of motivation is a very important factor in learning because it affects the achievement of college student learning outcomes. Motivation to learn to support college students to get the achievement they want so that it will greatly affect college student activity while studying. Motivation also plays a role in making someone feel happy with the learning process they follow so that it can trigger enthusiasm in learning which makes college students easily get good learning outcomes.

\section{CONCLUSION AND RECOMMENDATION}

After analyzing the data and the results that are processed using multiple logistic regression analysis techniques, it can be conclude that several things can be concluded. The quality of teaching lecturers does not directly affect college student learning achievement. This is a concern for lecturers to be able to improve their teaching performance, including by utilizing learning media properly, because there is a significant positive relationship between interactive media on increasing college student learning achievement. So that it attracts college students to be active and can grow their learning motivation. Because there is a significant positive relationship between college students' learning motivation on their learning achievement. This study recommends further research to examine the effect of lecturer competence on online lectures during the Covid-19 pandemic.

\section{REFERENCES}

Abbasi, A. S., \& Mir, G. M. (2012). Impact of Teacher' s Ability, Student's Work Ethics and Institutional Environment on Student Performance of University of Gujrat University of Gujrat Pakistan. 12(4), 572-579.

Ahmed, K., \& Alzubi, A. (2021). Explored Jordanian Math Teacher' $s$ Practices, and Belief Change in Implementing Mobile Applications in Education. 28(1), 9-25.

Akmal, M., Mohzan, M., Hassan, N., \& Abd, N. (2013). The Influence of Emotional Intelligence on Academic Achievement. Procedia - Social and Behavioral Sciences, 90(InCULT 2012), 303-312.

Akomolafe, C. O., Adesua, V. O., Foundations, E., \& Studies, C. (2016). The Impact of Physical Facilities on Students' Level of Motivation and Academic Performance in Senior Secondary Schools in South. 7(4), 38-42.

Al-mutairi, A. (2011). Factors Affecting Business Students ' Performance in Arab Open University: The Case of Kuwait. 6(5), 146-155. https://doi.org/10.5539/ijbm.v6n5p146

Alam, Y. (2018). Kompetensi Dosen, Motivasi Belajar Mahasiswa dan Dampaknya terhadap Prestasi Mahasiswa dalam Pembelajaran Pengantar Ekonomi (studi pada mahasiswa program studi Manajemen Informatika AMIK Bina Sriwijaya Palembang). Jurnal Manajemen Dan Bisnis Sriwijaya, 16(1), 23-30.

Amelia, R. (2019). On Using of a Mobile Learning in Teaching History at UIN Imam Bonjol Padang: A Research and Development Model. 26(2), 191-203.

Apriyanto, M. T., \& Herlina, L. (2020). Analisis Prestasi Belajar Matematika pada Masa Pandemi Ditinjau dari Minat 
Belajar Siswa. Seminar Nasional Dan Diskusi Panel Pendidikan Matematika, 1 , 135-144. http://proceeding.unindra.ac.id/index.php /DPNPMunindra/article/view/4774

Arafah, K. (2017). Pengaruh Sarana Prasarana Akademik, Kualitas Mengajar Dosen, Atmosfer Akademik, Dan Motivasi Belajar Terhadap Prestasi Belajar Mahasiswa. PARAMETER: Jurnal Pendidikan Universitas Negeri Jakarta, 29(2), 167-184. https://doi.org/10.21009/parameter.292.0 5

Bonney, E. A., Amoah, D. F., Micah, S. A., Ahiamenyo, C., \& Lemaire, M. B. (2015). The Relationship between the Quality of Teachers and Pupils Academic Performance in the STMA Junior High Schools of the Western Region of Ghana. 6(24).

Buska, W. (2020). Lecturer s' Speech Acts in Arabic Language Learning Interactions at UIN Sulthan Thaha Saifuddin Jambi. 27(1), 41-57.

Hakim, A. (2015). Contribution of Competence Teacher ( Pedagogical , Personality, Professional Competence and Social ) On the Performance of Learning. 1-12.

Handhika, J. (2012). Efektivitas media pembelajaran im3 ditinjau dari motivasi belajar. Jurnal Pendidikan IPA Indonesia, 1(2), 109-114.

Hew, K. F., Jia, C., Gonda, D. E., \& Bai, S. (2020). Transitioning to the " new normal " of learning in unpredictable times: pedagogical practices and learning performance in fully online flipped classrooms. International Journal of Educational Technology in Higher Education.

Khoiroh, N., Munoto, D., \& Anifah, L. (2017). Pengaruh Model Pembelajaran Blended Learning dan Motivasi Belajar Terhadap Hasil Belajar Siswa. Jurnal Penelitian Ilmu Pendidikan, 10(2), 97-
110.

Kumar, N., Holla, R., Kumar, A., Sriram, R., Nair, N., Rai, S., \& Najiza, H. (2015). Association Of Emotional Intelligence With Academic Performance Among Medical Students In South India. 8(2), 2 4.

Leitão, R., Maguire, M., Turner, S., \& Guimarães, L. (2021). A systematic evaluation of game elements effects on students motivation. Education and Information Technologies, 0123456789.

Miguel, L., \& Santos, D. (2021). Self-Efficacy and Career Decision of Pre-Service Secondary School Teachers: A Phenomenological Analysis. 14(1), 521536.

Munastiwi, E. (2020). Colorful Online Learning Problem of Early Childhood Education During the Covid-19 Pandemic. 27(3), 227-235.

Murti, R. W., \& Prasetio, A. P. (2018). Pengaruh Kompetensi Dosen terhadap Prestasi Akademik Mahasiswa Fakultas Ekonomi dan Bisnis Telkom University. Jurnal Penelitian Pendidikan, 18(2), 94102.

Mushtaq, I., \& Khan, S. N. (2012). Factors Affecting Students' Academic Performance. 12(9).

Mustaqim, I. (2020). Pengaruh Kompetensi Dosen, Kurikulum Dan Motivasi Terhadap Prestasi Belajar Mahasiswa. Reslaj : Religion Education Social Laa Roiba Journal, 1(1), 63-75.

Nirfayanti, N., \& Nurbaeti, N. (2019). Pengaruh Media Pembelajaran Google Classroom Dalam Pembelajaran Analisis Real Terhadap Motivasi Belajar Mahasiswa. Proximal Jurnal Penelitian Matematika Dan Pendidikan Matematika, 2(1), 50-59. 1

Nkomo, L. M., Daniel, B. K., \& Butson, R. J. (2021). Synthesis of student engagement with digital technologies: a systematic review of the literature. International 
Journal of Educational Technology in Higher Education, 1-26.

Rahmi, U. (2021). Message Design of Printed and Digital Material to Meaningful Learning. 28(1), 26-34.

Ramdani, A., Jufri, A. W., \& Jamaluddin, J. (2020). Pengembangan Media Pembelajaran Berbasis Android pada Masa Pandemi Covid-19 untuk Meningkatkan Literasi Sains Peserta Didik. Jurnal Kependidikan: Jurnal Hasil Penelitian Dan Kajian Kepustakaan Di Bidang Pendidikan, Pengajaran Dan Pembelajaran, 6(3), 433.

Ramli, A., Zain, R. M., Campus, C., Chepa, P., \& Bharu, K. (2018). The Impact Of Facilities On Student ' $S$ Academic Achievement. 30(2).

Ritonga, A. W., Ritonga, M., Nurdianto, T., Kustati, M., Rehani, Ahmad, L., Yasmadi, \& Pahri. (2020). E-Learning Process of Maharah Qira'ah in Higher Education during the Covid-19 Pandemic. International Journal of Higher Education, 9(6).

Ritonga, A. W., Ritonga, M., \& Septiana, V. W. (2021). Crossword puzzle as a learning media during the covid-19 pandemic: HOTS, MOTS or LOTS? Crossword puzzle as a learning media during the covid-19 pandemic: HOTS, MOTS or LOTS?

Ritonga, A. W., Zulfida, S., Ritonga, M., Ardinal, E., \& Susanti, D. (2021). The Use of E-learning as an Online Based Arabic Learning Media for Students The Use of E-learning as an Online Based Arabic Learning Media for Students.

Ritonga, M., Kustati, M., \& Lahmi, A. (2021). Arabic as Foreign Language Learning in Pandemic COVID-19 as Perceived by Students and Teachers. 5(May), 75-92.

Senjahari, B., Kustati, M., Training, T., Training, T., Islam, U., Imam, N., \&
Padang, B. (2021). Learning Objectives and Environments : How Do They Affect Students, Motivation in English Language Learning ? 8(2), 492-507.

Sur, W. A. A., HasanahMinhatul, \& Mustofa, M. R. (2020). Analisis Motivasi Belajar Mahasiswa dengan Sistem Pembelajaran Daring Selama Masa Pandemi Covid-19. EQUATION Teori Dan Penelitian Pendidikan Matematika, ISSN 2599. 3291 (Cetak), ISSN 2614-3933 (Online), $3(2), 40-54$.

Syachtiyani, W. R., \& Trisnawati, N. (2021). Analisis Motivasi Belajar Dan Hasil Belajar Siswa Di Masa Pandemi Covid19. Prima Magistra: Jurnal Ilmiah Kependidikan, 2(1), 90-101.

Technol, J. E., Educ, H., Johnson, J. B., Reddy, P., Chand, R., \& Naiker, M. (2021). Attitudes and awareness of regional Pacific Island students towards e - learning. International Journal of Educational Technology in Higher Education.

Tokan, M. K., \& Imakulata, M. M. (2019). The effect of motivation and learning behaviour on student achievement. 39(1), 1-8.

Uline, C., Tschannen-moran, M., \& College, T. (2008). The walls speak: the interplay of quality facilities, school climate, and student achievement. 46(1), 55-73.

Wahyudi, P. H. P., \& Ratna Sari, M. M. (2019). Pengaruh Kecerdasan Emosional, Fasilitas Belajar dan Kompetensi Dosen Terhadap Persepsi Prestasi Akademik Mahasiswa Akuntansi. E-Jurnal Akuntansi, 29(3), 1083.

Winata, I. K. (2021). Konsentrasi dan Motivasi Belajar Siswa terhadap Pembelajaran Online Selama Masa Pandemi Covid-19. Jurnal Komunikasi Pendidikan, 5(1), 13. 